\title{
Urinary Assessment among Nigerians in Health and with Frequent Use of Non-steroidal Anti-inflammatory Drugs
}

\author{
Uduagbamen PK, ${ }^{1,2}$ Hamzat $\mathrm{MA}^{2}$ and Ehioghae $\mathrm{O}^{1}$
}

\begin{abstract}
Background: Proteinuria is a risk factor for the occurrence and progression of chronic kidney disease hence its use in screening, diagnosis and monitoring purposes. The use of untimed sample has become more common due to shortcomings associated with 24 hour urine collection.
\end{abstract}

Aim: To use urinary measures in comparing the kidney function of a healthy population with an apparently healthy population with frequent use of non-steroidal anti-inflammatory drugs (NSAIDs).

Methods: Two hundred participants submitted paired urine samples. Blood was collected for estimation of creatinine based glomerular filtration rate (GFR). Student t-test and Chi-square tests were used to compare means and proportions respectively.

Result: The prevalence of kidney dysfunction among NSAIDs users using eGFR, albumin creatinine ratio (ACR), protein creatinine ratio (PCR) and 24 hour urine protein (24HUP) were $22 \%, 18 \%, 16 \%$ and $11 \%$ while in the controls were $6 \%, 6 \%, 5 \%$ and $0 \%$ respectively. The albumin creatinine ratio (ACR) was most strongly correlated with GFR in NSAIDs users.

Conclusion: The prevalence of kidney dysfunction using eGFR, ACR, PCR and 24HUP in NSAIDs users were all higher than in the healthy controls. The correlation between GFR and ACR was strongest of all urinary measures hence the ACR was a more reliable measure of kidney function assessment in health and in frequent NSAIDs use.

Keywords: non-steroidal anti-inflammatory drugs, albumin creatinine ratio, protein creatinine ratio, 24-hour urine protein, glomerular filtration rate.

\footnotetext{
*Corresponding Author

Dr Peter Uduagbamen,

http://orcid.org/0000-0001-8349-236/

E-mail: petr.uduagbamen@gmail.com
}

'Division of Nephrology and Hypertension, Department of Internal Medicine, Babcock University/

Babcock University Teaching Hospital, Ilishan-Remo, Nigeria

${ }^{2}$ Nephrology Unit, Department of Internal Medicine, Federal Medical Centre, Abeokuta, Nigeria 


\title{
L'utilité des mesures urinaires dans l'évaluation de la fonction rénale chez les Nigérians en matière de santé et avec l'utilisation fréquente d'anti-inflammatoires non stéroïdiens
}

\author{
Uduagbamen PK, ${ }^{1,2}$ Hamzat $\mathrm{MA}^{2}$ and Ehioghae $\mathrm{O}^{1}$
}

\section{Résumé}

Contexte général de l'étude : La protéinurie est un facteur de risque d'apparition et de progression de l'insuffisance rénale chronique, d'où leur utilisation à des fins de dépistage, de diagnostic et de surveillance. L'échantillon non chronométré est devenu plus courant en raison de lacunes associées à la collecte d'urine sur 24 heures. Des études ont montré une bonne corrélation entre les mesures urinaires dans la maladie et dans la santé.

Objectif de l'étude : Déterminer l'utilité des mesures urinaires dans l'évaluation de la fonction rénale chez les utilisateurs d'AINS et en santé.

Méthodes de l'étude : Deux cents participants ont soumis des échantillons d'urine appariés et du sang a été collecté pour l'estimation du DFG basée sur la créatinine. Les variables continues en tant que moyenne avec écart-type ont été comparées à l'aide du Test d'Étudiant (Student). Les variables catégorielles sous forme de proportions avec des pourcentages ont été comparées à l'aide du test du chi carré. La corrélation a été effectuée par analyse de régression linéaire en utilisant la corrélation de Spearman.

Résultat de l'étude : L'âge moyen des utilisateurs d'AINS, des contrôles et des utilisateurs d'AINS souffrant de dysfonction rénale $(\mathrm{KD})$ était respectivement de 46,5 $\pm 14,5,46,0 \pm 14,5$ et $63,11 \pm 18,62$. La prévalence de KD parmi les utilisateurs d'AINS utilisant eGFR, ACR, PCR et 24HUP était de $22 \%, 18 \%, 16 \%$ et $11 \%$, tandis que chez les témoins étaient de $6 \%, 6 \%, 5 \%$ et $0 \%$ respectivement. L'ACR était fortement corrélé avec le DFG chez les utilisateurs d'AINS.

Conclusion : La prévalence de KD utilisant eGFR et ACR chez les utilisateurs d'AINS était de $22 \%, 18 \%, 16 \%$ et $30 \%$ et parmi les témoins sains étaient de $6 \%, 6 \%, 5 \%$ et $0 \%$ respectivement. La corrélation entre le DFG et les mesures urinaires était la plus forte avec l'ACR. L'ACR localisé dans l'urine semble être une mesure plus fiable de l'évaluation de la fonction rénale en santé et en maladie.

Mots-clés: Anti-inflammatoires non stéroïdiens, ratio albumine-créatinine, ratio protéine-créatinine, protéines urinaires sur 24 heures, taux de filtration glomérulaire

\section{*Corresponding Author}

Dr Peter Uduagbamen,

http://orcid.org/0000-0001-8349-236/

E-mail: petr.uduagbamen@gmail.com

'Division of Nephrology and Hypertension, Department of Internal Medicine, Babcock University/

Babcock University Teaching Hospital, Ilishan-Remo, Nigeria

${ }^{2}$ Nephrology Unit, Department of Internal Medicine, Federal Medical Centre, Abeokuta, Nigeria 


\section{INTRODUCTION}

Proteinuria is a risk factor and accelerator of kidney disease hence its use in the screening, diagnosis and monitoring of kidney disease. The 24-hour urine protein (24HUP) has traditionally been the gold standard in urine protein quantification (1). Recently, the untimed urine is increasingly being used in quantifying proteinuria and assessing kidney function. Huan et al reported the reliability of albumin creation ratio (ACR) in urine protein quantification in glomerular diseases (2). MedilasRosas et al (3) recommended the use of spot protein creatinine ratio (PCR) to estimate the 24HUP. Arogundade et al found proteinuria in $29.7 \%$ of participants in a community survey where they also found glycosuria of $4.5 \%$ (4). Alebiosu et al reported a close association between proteinuria (albuminuria) and retinopathy in a population with diabetic nephropathy.(5) Similarly, Brenyah et al in Ghana, found heavy proteinuria in $15.6 \%$ of type 2 diabetics.(6) Proteinuria quantification using the PCR is reported to be improved by analysis incorporating the urinary creatinine excretion.(7)

As a way of relating the urinary measures, the Japanese Society of Nephrology and the kidney disease outcome quality initiative (KDOQI) recommended urine PCR as a reliable replacement for $24 \mathrm{HUP}$, and also, that a urine PCR of $150 \mathrm{mg} / \mathrm{g}$ $(15 \mathrm{mg} / \mathrm{mmol})$ was equal to an ACR of $30 \mathrm{mg} / \mathrm{g}$ $(3 \mathrm{mg} / \mathrm{mmol} .(8,9)$ NSAIDs use is very common in low income nations due to the very low level of industrial mechanization which has necessitated the use of manual labor in farming and construction related industries. Schwartz et al (10) had reported that NSAIDs use for more than 4 weeks was a risk factor for progression from acute interstitial nephritis to chronic kidney disease. NSAIDs inhibit prostaglandins (PGs) actions, particularly $\mathrm{PGE}_{2}$. Upregulation of $\mathrm{PGE}_{2}$ is a major pathway to renal injury through podocyte injury, with RAAS activation, hypertension, edema, proteinuria, and renal scarring in prolonged use. NSAIDs induced low molecular weight (LMW) proteinuria is of tubular origin, although, nephrotic range proteinuria and nephrotic syndrome have been reported, secondary to glomerular injury.(11) Tubular metabolism of these proteins, in addition to the glomerular filtered proteins, worsen tubules injury and can progress to chronic tubulointerstitial nephrtis (12),

Most correlation studies on urine protein quantification have been on glomerular diseases, literature is scares in conditions with low molecular weight proteinuria, like NSAIDs induced tubulointerstitial nephritis. The GFR is the gold standard in assessing kidney function (13). Correlations between GFR and urinary measures could therefore be ways of determining the reliability of these measures in kidney function assessment. We are not aware of studies correlating these urinary (proteins) measures with the GFR among Nigerians in health and in frequent NSAIDs use. In this study, we therefore determined the utility of these urinary measures in assessing kidney function by correlating each with the GFR in a healthy population, and in frequent NSAIDs users.

\section{MATERIALSAND METHODS}

This observational, descriptive study was carried at the Federal Medical Centre, Abeokuta, Nigeria. Two hundred participants (100 frequent NSAIDs users and 100 age and sex matched controls), sixteen years and older, who gave informed written consent were consecutively recruited. Exclusion criteria were hypertension or use of antihypertensive drugs, sickle cell disease, diabetes or the use of hypoglycemic agents, kidney disease or transplant, infections, tumors, use of nephrotoxins and ongoing menstruation. The height and weight were measured using SECA standiometer and SECA weighing scale, with participants bare footed, and on light clothing. The participants were taught timed urine collection and each was given a 5 liter tetraoxosulphate- 6 acid $\left(\mathrm{H}_{2} \mathrm{SO}_{4}\right)$ treated plastic container and two universal specimen bottles. They were instructed to choose a day they were likely to be mostly indoor and to commence the 24HUP collection after completely emptying their first urine on waking up and discarding it (and to write down the time). All urine passed subsequently were emptied into the plastic container and exactly 24 hours from the time written down, they were to empty completely their last urine for the 24HUP test into the container and return same to the hospital central laboratory. About 30 minutes after the last urine, they urinated about $20 \mathrm{ml}$ into the universal bottle and brought both to the central laboratory. At submission, blood was taken to determine creatinine based eGFR. Female participants were thought on ways of determining the actual time of commencement and termination of their menstrual flow. Urine protein and creatinine were analyzed through the Calorimetric method and Jaffe rate reaction, respectively, using the Hitachi Modular Analyzer. The urine albumin was measured by turbidimetric assay. 


\section{DEFINITIONS}

Frequent NSAIDs users were defined as those that had used the drugs daily for at least a month prior to recruitment for study.(14)

Kidney dysfunction was defined as GFR $<60 \mathrm{ml} / \mathrm{min}$, using the, chronic kidney disease epidemiology collaboration(CKD-EPI) formula.(13)

Clinical proteinuria: $\mathrm{ACR}>30 \mathrm{mg} / \mathrm{mmol}(8,9)$

PCR $>50 \mathrm{mg} / \mathrm{mmol}$ and $24 \mathrm{HUP}>500 \mathrm{mg} /$ day. $(8,9)$

Hypertension as blood pressure $\geq 140 / 90 \mathrm{mmHg}$.(4)

Diabetes as fasting blood glucose $\geq 7.0 \mathrm{mmol}(6)$.

Data is expressed as mean with standard deviation using Student t-test and as proportions using Chi square Spearman correlation coefficient was used to determine the strength of association between the GFR and the urinary measures. The research followed the tents of the Declaration of Helsinki. The study was approved by the Human Ethics Committee of the Federal Medical Centre, Abeokuta.

\section{RESULTS}

Two hundred (102 females and 98 males) participants took part in the study. There was no statistical difference between the mean age of NSAIDs users and controls, $46.5 \pm 14.5$ years and $46.0 \pm 14.2$ years, $\mathrm{P}=0.38$. However, among the NSAIDs users, mean age of those with kidney dysfunction (KD) was significantly higher than those without $\mathrm{KD}, \mathrm{P}=0.001$. The demographic, clinical and laboratory features of NSAIDs users are compared with controls in Table 1.
The mean BMI and systolic and blood pressures of the NSAIDSs users were significantly higher than the controls, $\mathrm{P}=0.04, \mathrm{P}<0.001$ respectively. There was no significant difference between the mean diastolic BP of the NSAIDs users and the controls, $\mathrm{P}=0.06$. Using the GFR, ACR, PCR and 24HUP among the NSAIDs users, $22 \%, 18 \%, 16 \%$ and $11 \%$ had kidney dysfunction respectively. Using the GFR, ACR, PCR and $24 \mathrm{HUP}$ among the controls, $6 \%, 6 \%, 5 \%$ and $0 \%$ had kidney dysfunction respectively. The mean GFR and hemoglobin of NSAIDs users was significantly lower than the controls, $\mathrm{P}<0.001$ and $\mathrm{P}=0.02$ respectively. The serum creatinine, ACR, PCR and 24HUP of the NSAIDs users were significantly higher than the controls, $\mathrm{P}<0.001, \mathrm{P}<0.001$ and $\mathrm{P}<0.001$ respectively.

Table 2 compared the characteristics of NSAIDs users based on the status of their kidney function. The mean age of NSAIDs users with KD was statistically higher than for those without $\mathrm{KD}, \mathrm{P}<0.001$. The mean BMI, systolic and diastolic BP of NSAIDs users with KD were significantly higher than NSAIDs users without $\mathrm{KD}, \mathrm{P}=0.03, \mathrm{P}<0.001$ and 0.003 respectively. The mean hemoglobin and GFR of the NSAIDs users with kidney dysfunction were significantly lower than those without kidney dysfunction, $\mathrm{P}=0.02, \mathrm{P}<0.001$ respectively. The mean serum creatinine, ACR, PCR and 24HUP of NSAIDs users with kidney dysfunction were significantly higher than those who had no kidney dysfunction, $\mathrm{P}<0.001, \mathrm{P}<0.001, \mathrm{P}<0.001$ and $\mathrm{P}<0.001$ respectively.

Table 1: Comparing clinical and laboratory characteristics of NSAIDs users and controls

\begin{tabular}{|c|c|c|c|c|}
\hline Variables & $\begin{array}{l}\text { NSAIDs users } \\
\mathrm{N}=100(\%) \\
\text { Mean } \pm \text { SD }\end{array}$ & $\begin{array}{l}\text { Controls } \\
\mathrm{N}=100(\%) \\
\text { Mean } \pm \mathrm{SD}\end{array}$ & $\begin{array}{l}X^{2} \\
t \text { test }\end{array}$ & P-value \\
\hline \multicolumn{5}{|l|}{ Gender } \\
\hline Mean age, $y r s$ & $46.14 \pm 14.52$ & $46.04+14.21$ & 0.74 & 0.3 \\
\hline Males, yrs & $46.21 \pm 8.82$ & $46.02 \pm 8.4$ & 0.9 & 0.12 \\
\hline Females, yrs & $46.07 \pm 6.2$ & $46.05 \pm 18.2$ & 0.57 & 0.55 \\
\hline BMI, $\mathrm{kg} / \mathrm{m}^{2}$ : & $28.1+13.1$ & $26.4+13.2$ & 3.04 & 0.03 \\
\hline Systolic BP, $m m H g$ & $123 . \overline{50} \pm 10.46$ & $114.0+11.70$ & 5.8 & $<0.001$ \\
\hline Diastolic BP, $m m H g$ & $75.73+8.26$ & $74.53+7.20$ & 0.72 & 0.06 \\
\hline Hemoglobin, $g / d l$ & $12.78+1.26$ & $13.83+1.42$ & 3.14 & 0.02 \\
\hline S. Creatinine, umol/l & $98.12+13.69$ & $77.79+36.38$ & 5.76 & $<0.001$ \\
\hline GFR, $\mathrm{ml} / \mathrm{min}$ & $87.83+30.72$ & $115.01 \pm 26.92$ & 6.64 & $<0.001$ \\
\hline $\mathrm{ACR}, \mathrm{mg} / \mathrm{mmol}$ & $22.43 \pm 47.44$ & $11.62 \pm 4.23$ & 9.44 & $<0.001$ \\
\hline $\mathrm{PCR}, \mathrm{mg} / \mathrm{mmol}$ & $39.24 \pm 15.38$ & $14.88 \pm 5.41$ & 6.83 & $<0.001$ \\
\hline 24HUP, $m g / d a y$ & $402.27 \pm 23.42$ & $152.85 \pm 33.68$ & 7.24 & $<0.001$ \\
\hline Urine Creatinine, $\mathrm{mmol} / \mathrm{l}$ & $709.71 \pm 22.49$ & $1628.75 \pm 48.64$ & 11.25 & .001 \\
\hline
\end{tabular}

NSAIDs-non steroidal anti-inflammatory drugs, GFR-glomerular filtration rate, SD-standard deviation, BMI-body mass index, $B P$-blood pressure, ACR-albumin creatinine ratio, PCR-protein creatinine ratio, 24HUP-24 hour urine protein 
Table 2: Comparing characteristics of NSAIDs users based on the status of the kidney function

\begin{tabular}{lllll}
\hline Variables & $\begin{array}{l}\text { GFR }<60 \mathrm{ml} / \mathrm{min} \\
\mathrm{N}=22(\%)\end{array}$ & $\begin{array}{l}\text { GFR } \geq 60 \mathrm{ml} / \mathrm{min} \\
\mathrm{N}=78(\%) \\
\text { Mean } \pm \mathrm{SD}\end{array}$ & $\begin{array}{l}\mathrm{X}^{2} \\
\text { t test }\end{array}$ & P-value \\
& $13(59.09)$ & $38(48.71)$ & 3.86 & 0.01 \\
Females & $63.04 \pm 7.32$ & $41.84 \pm 8.27$ & 6.8 & $<0.001$ \\
Age, yrs & $29.43 \pm 12.80$ & $27.72 \pm 15.25$ & 2.86 & 0.03 \\
BMI, $\mathrm{kg} / \mathrm{m}^{2}:$ & $134.76 \pm 42.62$ & $119.82 \pm 22.14$ & 5.48 & $<0.001$ \\
Systolic BP, $\mathrm{mmHg}$ & $83.18 \pm 26.37$ & $73.94 \pm 11.12$ & 4.16 & 0.003 \\
Diastolic BP, $\mathrm{mmHg}$ & $11.98 \pm 2.52$ & $13.02 \pm 1.23$ & 3.61 & 0.02 \\
Hemoglobin, $\mathrm{g} / \mathrm{dl}$ & $114.25 \pm 32.45$ & $9344 \pm 19.56$ & 7.85 & $<0.001$ \\
S. creatinine, umol/l & $43.61 \pm 25.84$ & $99.42 \pm 23.21$ & 9.56 & $<0.001$ \\
GFR, $\mathrm{ml} / \mathrm{min}$ & $29.63 \pm 7.35$ & $20.61 \pm 4.46$ & 9.24 & $<0.001$ \\
ACR, $\mathrm{mg} / \mathrm{mmol}$ & $43.74 \pm 12.59$ & $38.11 \pm 23.45$ & 6.21 & $<0.001$ \\
PCR, $\mathrm{mg} / \mathrm{mmol}$ & $788.68 \pm 42.8$ & $592.7 .44 \pm 46.14$ & 9.13 & $<0.001$ \\
24HUP, $\mathrm{mg} /$ day & $235.53 \pm 8.45$ & $592.7 .44 \pm 46.14$ & 8.14 & $<0.001$ \\
Urine Creatinine, mmol/l & & & \\
\hline
\end{tabular}

NSAIDs-non steroidal anti-inflammatory drugs, GFR-glomerular filtration rate, SD-standard deviation, BMI-body mass index,

BP-blood pressure, ACR-albumin creatinine ratio, PCR-protein creatinine ratio, 24HUP-24 hour urine protein

Table 3: Relationship between urinary indexes of kidney dysfunction and eGFR stages in all participants

\begin{tabular}{|c|c|c|c|c|c|c|}
\hline Variables & $\mathrm{GFR}>90 \mathrm{ml} / \mathrm{min}$ & GFR 60-89 & GFR 45-59 & GFR 30-44 & GFR 15-29 & ANOVA \\
\hline $\begin{array}{l}\mathrm{ACR}, \\
\mathrm{mg} / \mathrm{mmol}\end{array}$ & $130(65.0)$ & $46(23.0)$ & $13(6.5)$ & $10(5.0)$ & $1(0.5)$ & $<0.001$ \\
\hline $\begin{array}{l}\text { PCR, } \\
\mathrm{mg} / \mathrm{mmol}\end{array}$ & $133(61.5)$ & $46(23.0)$ & $9(4.5)$ & $10(5.0)$ & $2(1.0)$ & $<0.001$ \\
\hline $\begin{array}{l}\text { 24HUP } \\
m g / d a y\end{array}$ & $128(64.0)$ & $42(21.0)$ & $14(7.0)$ & $13(6.5)$ & $3(1.5)$ & $<0.001$ \\
\hline
\end{tabular}

ACR-albumin creatinine ratio, PCR-protein creatinine ratio, 24HUP-24 hour urine protein, ANOVA-analysis of variance,

GFR-glomerular filtration rate.

\section{GRAPHS OF CORRELATIONS OF THE NSAIDS USERS}
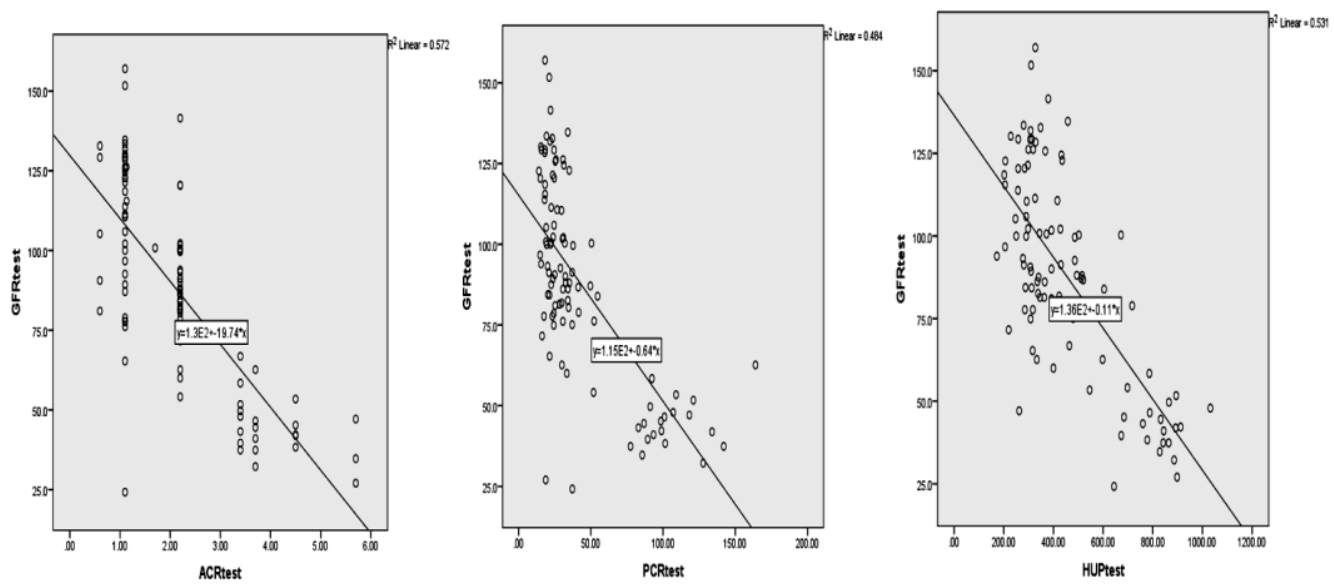

Figure 1: Upper: Significant negative correlation between eGFR and ACR, $\mathrm{r}=-0.756, \mathrm{P}<0.001$.

Middle: Significant negative correlation between eGFR and PCR, $r=-0.696, P<0.001$.

Lower: Significant negative correlation between eGFR and 24HUP, $r=-0.729, P<0.001$

Using the GFR, ACR, PCR and the 24HUP, there were significant differences in the proportion of participants that had kidney dysfunction between the NSAIDs users and controls, $\mathrm{P}<0.001, \mathrm{P}<0.001$, $\mathrm{P}<0.001$ and $\mathrm{P}<0.001$ respectively. Table 3 shows the relationship between urinary indexes of kidney dysfunction and the stages of kidney disease using the glomerular filtration rate.

As the eGFR reduced, and with increasing proteinuria, the sensitivity of the PCR and 24HUP increased. 


\section{GRAPHS OF CORRELATIONS OF CONTROL}
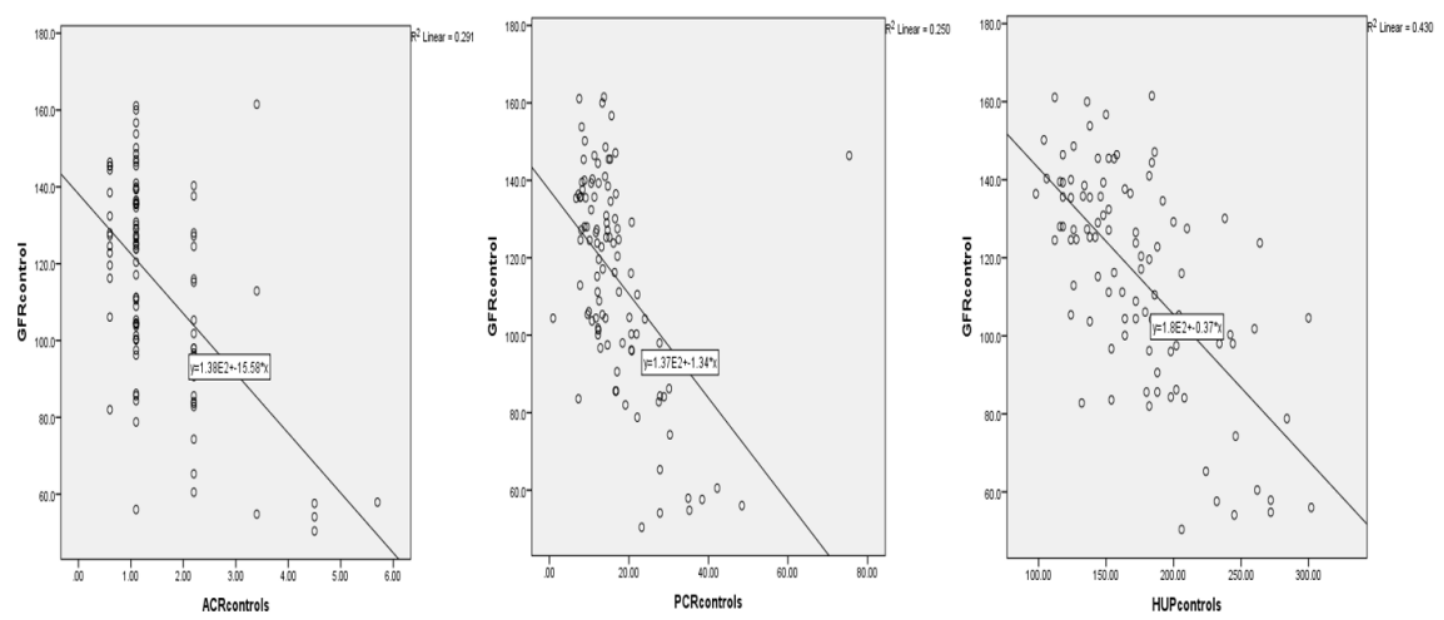

Figure 2: Upper: Significant negative correlation between eGFR and ACR, $\mathrm{r}=-0.540, \mathrm{P}<0.001$. Middle: Significant negative correlation between eGFR and $P C R, r=-0.500, P<0.001$.

Lower: Significant negative correlation between eGFR and 24HUP, $r=-0.656, P<0.001$

Figure 1 shows the negative correlation between the GFR and the urinary measures of ACR, PCR and the 24HUP, for the NSAIDs users. The negative correlations between the GFR and the urinary measures was strongest with the ACR, $\mathrm{r}=-0.756, \mathrm{p}<$ 0.001 , followed by the 24HUP, $r=-0.729, \mathrm{P}<0.001$. Figure 2 shows the negative correlations between the GFR and the ACR, PCR and the 24HUP for the controls. The 24HUP was most strongly correlated with the GFR, $\mathrm{r}=-0.656, \mathrm{p}<0.001$ followed by the $\mathrm{ACR}, \mathrm{r}=0.540, \mathrm{P}<0.001$.

\section{DISCUSSION}

We found in our series that NSAIDs causes proteinuria associated with a decline in kidney function, and this agrees with previous studies that reported increase excretion of both the LMW and HMW proteins from NSAIDs use.(11) Despite NSAIDs anti-inflammatory properties, their proteinuric effect is well reported and attributable to inhibition of renal vasodilation by suppressing the activities of renal prostaglandins. Recurrent renal hypoperfusion induces ischemic changes and could progress to tubulointerstitial fibrosis (from recurrent ischemic-reperfusion injury). NSAIDs effects can be heighten in dehydration which can be caused by diuretics and exercise (15).

Urinary protein quantification could be a very reliable way of estimating blood sugar control over a preceding period. $\mathrm{HbA} 1 \mathrm{c}$ is reported to correlate better with urine ACR than eGFR in type 2 diabetic nephropathy, with or without good glucose control.(16) Again, albuminuria typically signifies tubuloglomerular damage as excess glomerular filtered protein are metabolized by tubules, resulting in tubular proteinuria. Moreover, the use of antiproteinuric agents directly reduces or terminates albuminuria whereas the likely increase in eGFR seen, mostly reflects improving kidney function.(17) However, Lamb et al found very low sensitivity and poor positive predictive value (PPV) in dip strips testing, for low level proteinuria due to the very low sensitivity of dip strips reagents to albumin.((18) The authors concluded that dip strip positivity points to moderate-to-heavy proteinuria, therefore, its use in screening for proteinuria was not reliable.

The sensitivity of urinary ACR was higher than the PCR in this study and this agree with recommendations by the Kidney Disease Improving Global Outcome (KDIGO) in 2013 and the National Institute for Health and Clinical Excellence (NICE) in 2014. $(19,20)$

Albuminuria, being the commonest form of proteinuria in kidney disease, denotes tubuloglomerular disease whereas LMW proteinuria denotes tubular damage. NSAIDs induced proteinuria therefore, has lesser tendencies for analytical errors in estimating albuminuria compared to proteinuria.(21) A poor relationship is reported between ACR and PCR in low level proteinuria. The ratio of albumin-to-protein in urine increases with the 
amount of protein and correlations between the two are stronger in heavy proteinuria, though nonnephrotic, likely due to increasing sensitivity of PCR at higher levels of proteinuria (19).

The presence of megalin and cubulin in the tubules mediate absorption of both tubule secreted and glomerular filtered proteins and plays a major part in reducing proteinuria. Researchers have attributed the poor sensitivity of PCR and its poor association with ACR and 24HUP in nephrotic syndrome (NS) to the markedly reduced megalin and cubulin, in nephrotic syndrome (22). The associations between the various urine measures have be reported to be dependent on the socio-demographics, kidney function, analytical methods and procedures (23).

Our study found a slight female predominance in NSAIDs use and a greater risk of nephrotoxicity in them compared with males, similar to findings by De Broe et al.(24) Females, with relative smaller sizes, receive larger drug quantity per tissue mass compared to males, in addition, their larger fat tissue deposit cause higher volume of distribution, therefore more toxicities in excess dosages (25). Again, females, having lesser P450 enzyme inducers compared to males, experience lesser drug degradation, thereby receiving larger drug quantity (26). The BMI was higher in NSAIDs users, moreso in NSAIDs users with kidney dysfunction. Amira et al reported a higher prevalence of albuminuria in the obese than the general population.(27) Obesity is associated with endothelial damage, albuminuria and increases the risk of atherosclerosis thereby increasing the risk for cardiovascular events and death(28).

Even within normal ranged BP, NSAIDs users had higher mean blood pressure. Increased hepatic production of more atherogenic lipids, as a response to lower serum albumin from urinary losses, accelerates atherosclerosis with attendant higher blood pressures (29). The effects of NSAIDs on the body hemodynamics result in elevated nitrogenous waste in the blood and is multifactorial in origin. The inhibition of $\mathrm{PGE}_{2}$ and $\mathrm{PGI}_{2}$, afferent arteriolar constriction, reductions in renal and plasma blood flow, and glomerular filtration pressures, lead to reduced solute clearance and therefore retention of nitrogenous waste. $(10,11)$ Anemia was more prevalent among NSAIDs users in this study, likely from reduced erythropoietin production from the peritubular interstitium, a commonly affected site in NSAIDs induced nephropathy. This is also corroborated by the finding of anemia that is out of proportion to the degree of kidney dysfunction seen in this group (30).

We encountered some limitations in this study. The level of compliance with prescribed 24 hour urine collection could not be ascertained. Information on co-morbid conditions was self-reported and from participants' case files, disease conditions that could affect results could be present without been discovered. The commonest analgesic agent, paracetamol, was not included among the NSAIDs despite findings that very prolonged use could be nephrotoxic.

\section{CONCLUSION}

The use of NSAIDs is associated with adverse renal outcome, elevated blood pressure, anemia and proteinuria. Urinalysis, in screening for kidney disease, diagnosing and monitoring kidney function, is easy and reliable, particularly with good understanding of the collection methods by participants. The untimed sample has the advantage of been easy to collect and gives more reliable results than the total protein. The correlation between GFR and urinary measures in NSAIDs users was strongest with ACR, making ACR the most reliable measure. However, the 24HUP had the strongest correlation with GFR in healthy controls. Larger studies involving all races are needed for better understanding and universal application of findings.

\section{ACKNOWLEDGEMENTS}

Dr Fidelis Ojeblenu and Dr Nosirudeen Bello, both Senior Consultant Orthopedic Surgeons, Federal Medical Centre, Abeokuta for giving us access to recruit their patients for the study.

\section{CONFLICT OF INTEREST}

The authors declare that there is no conflict of interest in the publication of this paper. 


\section{REFERENCES}

1. Hillege HL, Fidler V, Diercks GFH, van Gilst WH, de Zeeuw, van Veldhuisen.et al. Urinary albumin excretion predicts cardiovascular and noncardiovascular mortality in general population. Circulation. 2002; 106(14): 1777-82.

2. Huan L, Yuezhong L, Chao W, Tao TH. The urine albumin-to-creatinine ratio is a reliable indicator for evaluating complications of chronic kidney disease and progression in IgA nephropathy in China Clinics 2016; 7(5): 243-250

3. Medina-Rosas J, Gladman DD, Su J, Sabapathy A, Urowitz MB, Touma Z. Utility of untimed single urine protein/creatinine ratio as a substitute for $24-\mathrm{h}$ proteinuria for assessment of proteinuria in systemic lupus erythematosus. Arthritis Research \& Therapy. 2015; 17: 296.

4. Arogundade F, Abubakr S, Muzamil H, Aderoju G, Funmilayo $\mathrm{O}$ et al. Undiagnosed hypertension and proteinuria in a market population in Ile-Ife, Nigeria. Arab J Nephrol Transpl. 2011; 4(3): 141-146

5. Alebiosu OC. Clinical Diabetic Nephropathy in a Tropical African Population West Afr J Med 2003; 22(2): $152-5$

6. Brenyah RC, Ephraim RKD, Owiredu WKBA, Eghan BA, Quaye L. Prevalence and determinants of proteinuria among type 2 diabetics in Kumasi, Ghana. J Med Biomed Sci 2013; 2:1

7. Chen CF, Yang WC, Yang CY, Li SY, Ou SM, Chen YT et al. Urinary protein/creatinine ratio weighted by estimated urinary creatinine improves the accuracy of predicting daily proteinuria. Am J Med Sci 2015; 349(6): 477-87

8. Evidence-based Clinical Practice Guideline for CKD 2013. Clin Exp Nephrol 2014; 18, 346-423

9. National Kidney Foundation. K/DOQI Clinical Practice Guidelines for Chronic Kidney Disease: evaluation, classification, and stratification. Am J Kidney Dis. 2002; 39(suppl 1):S1-S266

10. Schwarz A, Krause PH, Kunzendorf U, Keller F, Distler A. The outcome of acute interestial nephritis: risk factors for the transition from acute to chronic interstistial nephritis. Clin Nephrol 2000; 54(3): 17990.

11. Weir MR. Renal effects of nonselective NSAIDs and coxibs. Cleve Clin J Med. 2002; 69(Suppl 1):SI53-8

12. Jayasinghe $\mathrm{K}$. White $\mathrm{SM}$, Kerr PG, MacGregor D, Stark Z, Wilkins E et al. Isolated proteinuria due to CUBN homozygous mutation - challenging the investigative paradigm. BMC Nephrology 2019; 20: 330.
13. Levey AS, Stevens LA, Schmid CH, Zhang YL, Castro AF, Feldman HI, et al. CKD-EPI (Chronic Kidney Disease Epidemiology Collaboration) A new equation to estimate glomerular filtration rate. Ann Intern Med. 2009; 150(9): 604-612

14. Paulose-Ram R, Hirsch R, Dillon C, Gu Q. Frequent Monthly Use of Selected Non-Prescription and Prescription Non-Narcotic Analgesics Among U.S. Adults. Pharmacolepidemiol Drug Saf 2005; 14(4): 257-66

15. Martínez S, Aguilo A, Moreno C, Lozano L, Tauler P. Use of Non-Steroidal Anti-Inflammatory Drugs among Participants in a Mountain Ultramarathon Event. Sports (Basel).2017; 5, 11

16. Haque N, Debnath BC, Ibrahim M, Sirajuddin K, Majumder M, Hossain M S. Association of HbAlc with Urinary ACR and eGFR in type-2 diabetes mellitus. Pulse. 2011; 5, 1.

17. Bakris GL, Molitch M. Microalbuminuria as a Risk Predictor in Diabetes: The Continuing Saga. Diabetes Care 2014; 37(3): 867-875.

18. Lamb EJ, MacKenzie E, Stevens PE. How should proteinuria be detected and measured? Ann Clin Biochem 2009; 46: 205-217

19. Kidney Disease: Improving Global Outcomes (KDIGO) 2012: Clinical practice guideline for the evaluation and management of chronic kidney disease. Kidney Int 2013; 3(1): 1-150

20. Chronic Kidney Disease (Partial Update): Early identification and management of chronic kidney disease in adults in primary and secondary care. Clinical Guideline 182 Methods, evidence and recommendations. National Institute for Health and Care Excellence, 2014. Assessed 24th June 2016

21. Weaver RG, James MT, Ravani P, Weaver CGW, Lamb EJ, Tonelli M et al. Estimating Urine Albuminto-Creatinine Ratio From Protein-to-Creatinine Ratio: Development of Equations Using Same-Day Measurements. J Am Soc Nephrol 2020 31(3): 591601.

22. Ogasawara S, Hosojima M, Kaseda R, Kabasawa H, Yamamoto-Kabasawa $\mathrm{K}$, Kurosawa $\mathrm{H}$, et al. Significance of urinary full-length and ectodomain forms of megalin in patients with type 2 diabetes. Diabetes Care. 2012;35(5): 1112-8.

23. Thakur SK, Dhakal SP, Parajuli S, Sah AK, Nepal SP, Paudel BD. Microalbuminuria and Its Risk Factors in Type 2 Diabetic Patients. J Nepal Health Res Counc 2019; 17(1): 61-65

24. De Broe ME, Elseviers MM. Over-the-Counter Analgesic Use JASN 2009, 20 (10) 2098-2103. 
25. Nicolson TJ, Mellor HR, Roberts RRA. Gender differences in drug toxicity. Trends Pharmacol Sci. 2010; 31(3): 108-114

26. Corsini A, Bortolini M. Drug-Induced Liver Injury: The Role of Drug Metabolism and Transport. J Clin Pharmacol 2013; 53(5): 463-474

27. Amira CO, Sokunbi DO, Dolapo D, Sokunbi A. Prevalence of obesity, overweight and proteinuria in an urban community in South West Nigeria. Niger Med J 2011; 52: 110-113

28. Kovesty CP, Furth SL, Zoccali C. Obesity and kidney disease. Hidden consequences of the epidemic. Afr J Prim Health Care Fam Med 2017; 9(1): 1435

29. Horl WH. Nonsteroidal Anti-Inflammatory Drugs and the Kidney. (Pharmaceuticals Basel) 2010; 3(7): 2291-2321.

30. Han JS, Lee MJ, Park KS, Han SH, Yoo TH, Oh KH et al. Albuminuria as a Risk Factor for Anemia in Chronic Kidney Disease: Result from the KoreaN Cohort Study for Outcomes in Patients With Chronic Kidney Disease (KNOW-CKD) Plus ONE 2015; 10(10): e0139747. 